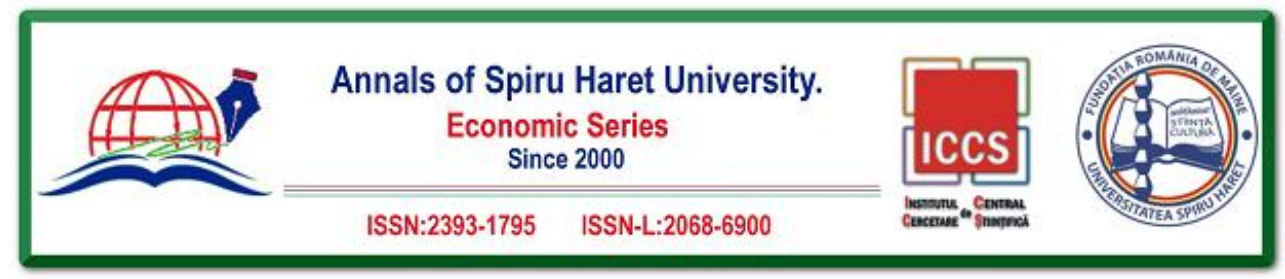

Issue 3/2018

\title{
MILLENNIALS: A NEW TREND FOR THE TOURISM INDUSTRY
}

\author{
Bogdan SOFRONOV ${ }^{1}$ \\ ${ }^{1}$ University Politehnica of Bucharest, 313 Splaiul Independenței, \\ Bucharest, 060042, Romania, Email: bogdansofronov@yahoo.com
}

How to cite: SOFRONOV, B. (2018). "Millennials: A New Trend for the Tourism Industry." Annals of Spiru Haret University. Economic Series, 18(3), 109-122, doi: https://doi.org/10.26458/1838

\begin{abstract}
The purpose of this paper is how millennials change and influencing the tourism industry and their importance for travel in the world.

Having grown up with near-ubiquitous internet access and beginning their professional careers in the wake of a financial crisis, millennials are using technology to make savvy travel-buying decisions, largely based on the perceived authenticity of the experience they are offered.

Millennials travel more than any other demographic. On average, they take 35 days of vacation each year, and they're also bucking the trend by increasing their annual travel spend as other generations intend to be more conservative with their cash.

Millennial travellers are interested in authenticity, fulfilment and sustainability. That's a message that tour operators, travel agents and the entire travel industry needs to understand.

The millennials represent 27 percent of the global population or about 2 billion people.
\end{abstract}

Keywords: millennials; travel; tourism; tourism industry; international tourism.

JEL Classification: $Z_{30}, Z_{32}$

\section{Introduction}

The millennials generation continues to have a significant influence on how the hotel industry is developing its offer and on the types of services the hotel proposes. 


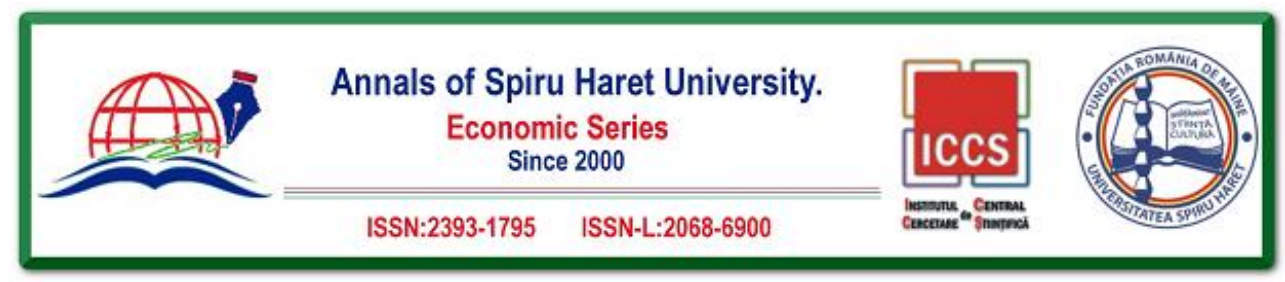

Issue $3 / 2018$

Millennials travel differently from previous generations and have different expectations from accommodation units. For them, experiences are more important than tangible products, and hoteliers have to rethink their offerings accordingly.

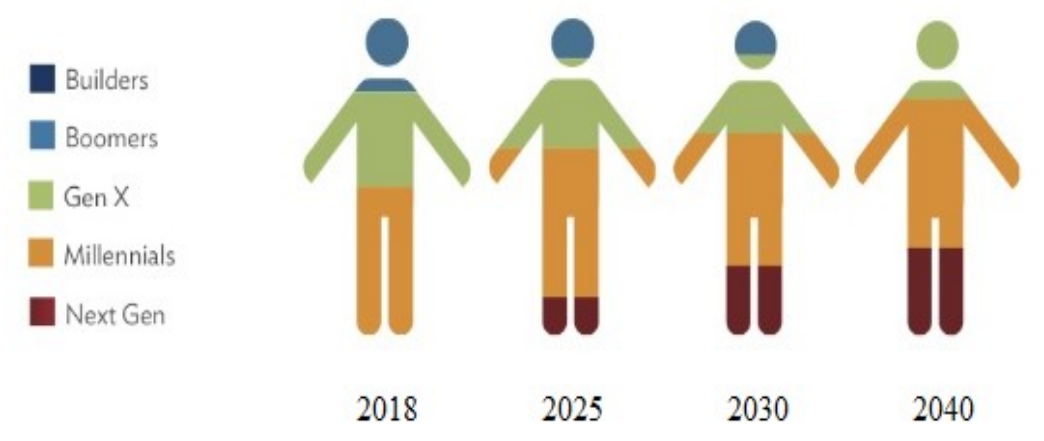

Fig. 1. Millennials in the World

Source: personal contribution

Millennials are looking for new experiences and the tourism industry should focus on providing experiences, not just functionalities. There have been days when the expectations of a tourist from an accommodation unit were limited to a comfortable bed, a clean bathroom and a safe location. Millennials want more; they differ from their parents' generation in purchasing behaviour. If the representatives of older generations prefer to spend their money on tangible objects, the millennia tend to spend more on experiences such as holidays and travels. It is important for hotel owners to consider this.

Millennials are not too interested in staying in their hotel rooms and prefer to go to open public spaces to meet new people or meet up with friends. The lobby is the first thing a guest sees when entering a hotel, so make sure it is functional and encourage socialization and entertainment. A lobby where guests have entertainment or lounge areas, with TVs running matches, invites guests to socialize with other people and provide them with a space to create connections.

One way to reach the heart of the millennials is to offer diversified foods in hotel restaurant. Local ingredients bought directly from manufacturers, specific dishes from the hotel's operating area, local crafted beers, or late lobby snacks. Millennials will have a tendency to go out to eat or drink, but having fresh and tasty food is an advantage for the hotels. These young people appreciate their 110 


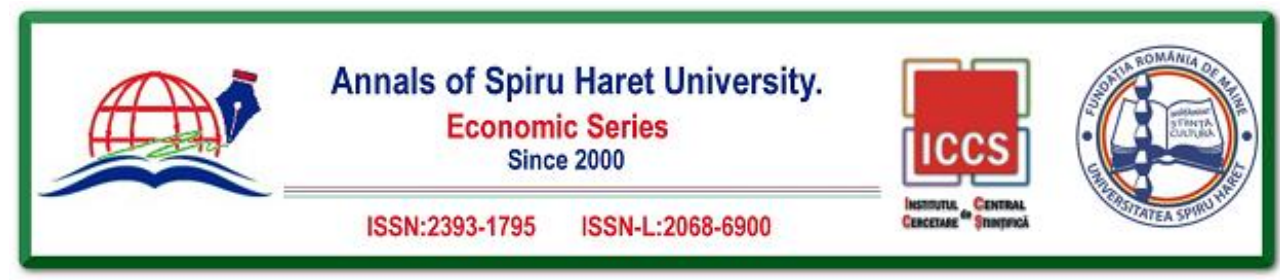

Issue 3/2018

culinary options late at night, which they can take on their way to their room or room service until late at night.

Table 1. Most Popular Destinations for Millennials

\begin{tabular}{|c|c|c|}
\hline \multicolumn{3}{|c|}{ Top 10 most popular destinations for millennials (\%) } \\
\hline 1. & Spain & $18 \%$ \\
\hline 2. & Australia & $15 \%$ \\
\hline 3. & UK & $14 \%$ \\
\hline 4. & New Zealand & $12 \%$ \\
\hline 5. & Thailand & $11 \%$ \\
\hline 6. & Italy & $10 \%$ \\
\hline 7. & Portugal & $9 \%$ \\
\hline 8. & Costa Rica & $5 \%$ \\
\hline 9. & Peru & $4 \%$ \\
\hline 10. & Philippines & $2 \%$ \\
\hline
\end{tabular}

Source: personal contribution

\section{Literature Review}

My research paper entitled: Millennials: A New Trend for the Tourism Industry, is written after I've documented on the basis of the following published articles:

1. 'Understanding millennials' tourism experience: values and meaning to travel as a key for identifying target clusters for youth (sustainable) tourism" written by Elena Cavagnaro, published on Journal of Tourism Futures.

2. "The role of development of transport tourism in economic growth" written by Flora Alasgarova and published on Annals of Spiru Haret University. Economic Series.

3. "Millennials' travel motivations and desired activities within destinations: A comparative study of the US and the UK" written by Paulo Rita and published on Current Issues in Tourism.

4. "Tourism and the new generations: emerging trends and social implications in Italy" written by Salvatore Monaco and published on Journal of Tourism Futures.

Millennials: A New Trend for the Tourism Industry

Millennials have quickly become one of the most powerful forces in the travel industry. This generation, which includes adults between the ages of 24 and 35, have money to spend and they want to use it on experiential travel to new and exotic destinations. Millennials are looking for a different type of vacation 


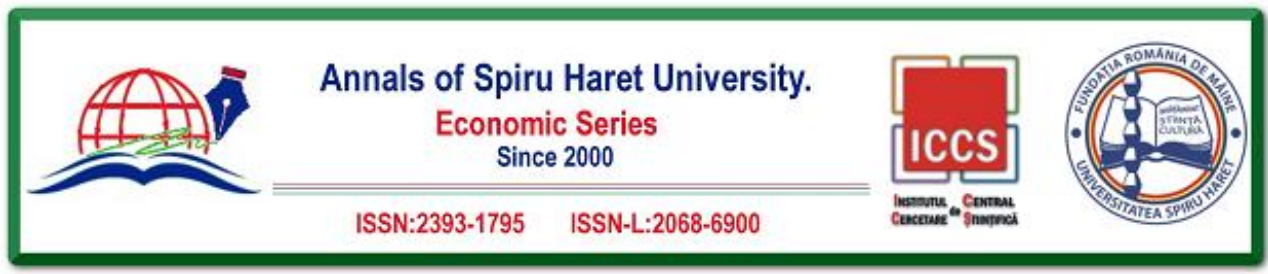

\section{Issue $3 / 2018$}

experience than their parents and grandparents did, and tour and activity providers would be wise to take note. [Rezdy, 2018]

Millennials love to travel, not only are they inclined to take extended-stay trips that encourage cultural immersion, but they also enjoy booking spontaneous weekend getaway whenever possible. Given the fact that many millennials are delaying marriage and having children, they often have more discretionary income to spend than other generations and travel is typically a top priority. They would rather book a trip than purchase a nicer car or a luxury home product. [Rezdy, 2018]

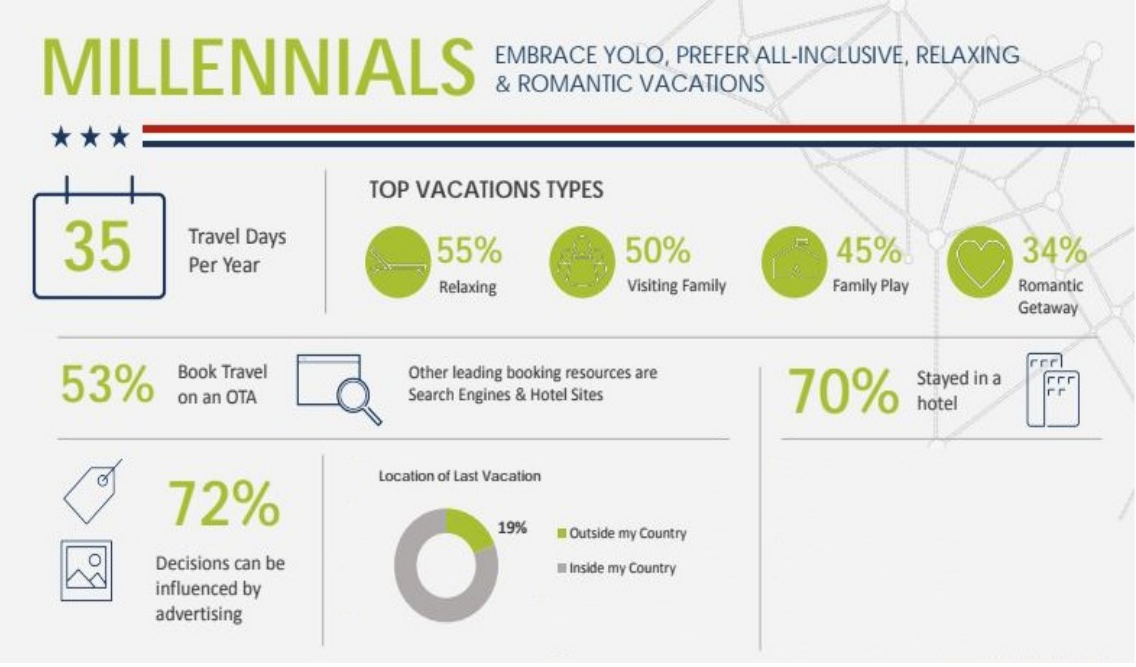

Fig. 2. Millennials Vacations Types

Source: "Millennials: An In-depth Look into the Travel Segment," accessed July 2, 2018, https://www.rezdy.com/blog/millennials-depth-look-travel-segment-infographic/

The data shows that 55 percent of millennials travel in order to relax. Many of them came of age during the recession, and they are used to dealing with constant connection with their peers as well as their professional network. This added stress has increased the need for relaxing getaways that allow them to unplug. In fact, 83 percent of millennials choose to vacation at all-inclusive resorts where they have everything they need right at their fingertips. [Rezdy, 2018]

As opposed to the younger Generation Z, millennial travellers are more likely to be influenced by an advertising campaign than they are by a social media campaign. 


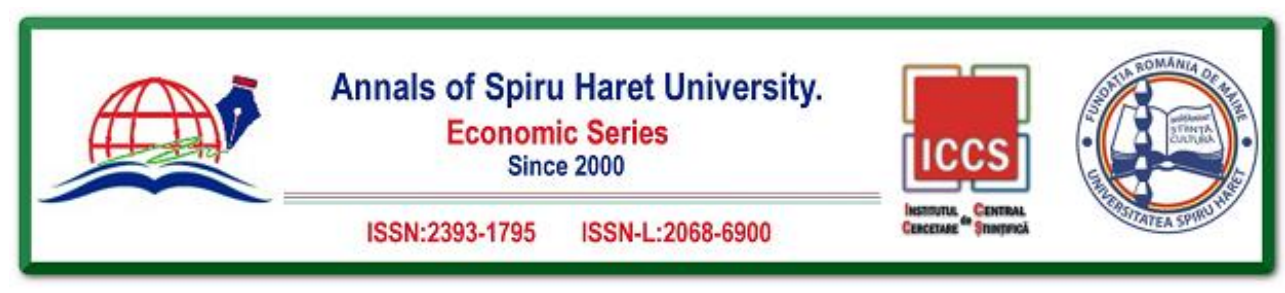

Issue 3/2018

More than 72 percent of millennial travellers say that a solid advertising promotion can convince them to book travel arrangements. For the most part, online advertising including retargeting and other social strategies is the best way to connect and engage with millennials. While these travellers have money to spend, they still like to get a great deal. Approximately 92 percent of millennials report that they won't finalize their booking until they feel they have the best deal possible. [Rezdy, 2018]

Millennials may love to take selfies, but they want their vacations to be more than just an endless string of photo opportunities. Millennials are more likely to book a trip that allows them to be outdoors and experience something new, such as an informative tour or an immersive activity. Nearly 83 percent report that it is important to them to book a travel experience that allows them to cross an item off of their bucket list. [Rezdy, 2018]

Millennials are much more sociable than older business travellers, and are also most concerned about their personal safety. [Carlson Wagonlit Travel, 2018]

A full $58 \%$ of millennials travel with others, $43 \%$ travel with colleagues, and $15 \%$ with friends or family. In stark contrast, nearly three-quarters $(71 \%)$ of baby boomers travel alone. Sometimes, they travel with colleagues $(23 \%)$, but they rarely bring along friends or family $(6 \%)$. Generation $\mathrm{X}$ travellers are somewhere in the middle, with $58 \%$ travelling alone, $31 \%$ with a colleague, and $11 \%$ with friends or family. [Carlson Wagonlit Travel, 2018]

Nearly half of millennials (45\%) contact friends or family while travelling more than once per day, compared to $38 \%$ of generation $X$ and $29 \%$ of baby boomers. Millennials connect more with clients while travelling (55\%) than generation $\mathrm{X}$ (44\%) and boomers (35\%) - and with co-workers (41\%) versus $28 \%$ of the generation X and only 19\% of the boomers. [Carlson Wagonlit Travel, 2018]

The use of technology also varies dramatically between generations. When it comes to connecting with family, boomers prefer to use their phone (51\%), compared to barely half of generation X (44\%) and only $39 \%$ of millennials. Conversely, a full $31 \%$ of millennials use Skype, compared to $24 \%$ of generation X, and only $17 \%$ of boomers. [Carlson Wagonlit Travel, 2018]

When it comes to staying in contact with colleagues, email is everyone's preferred method. However, here too, the generations differed markedly. More than half $(52 \%)$ of the boomers use email, compared to $46 \%$ of the generation $X$ and only $34 \%$ of the millennials. When it comes to using the phone, $30 \%$ of millennials and $22 \%$ of both boomers and generation $\mathrm{X}$ prefer to pick up the phone and call colleagues. [Carlson Wagonlit Travel, 2018] 


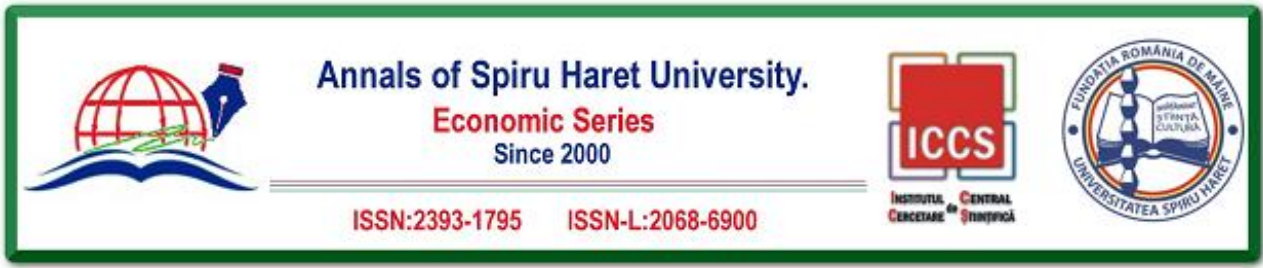

Issue $3 / 2018$

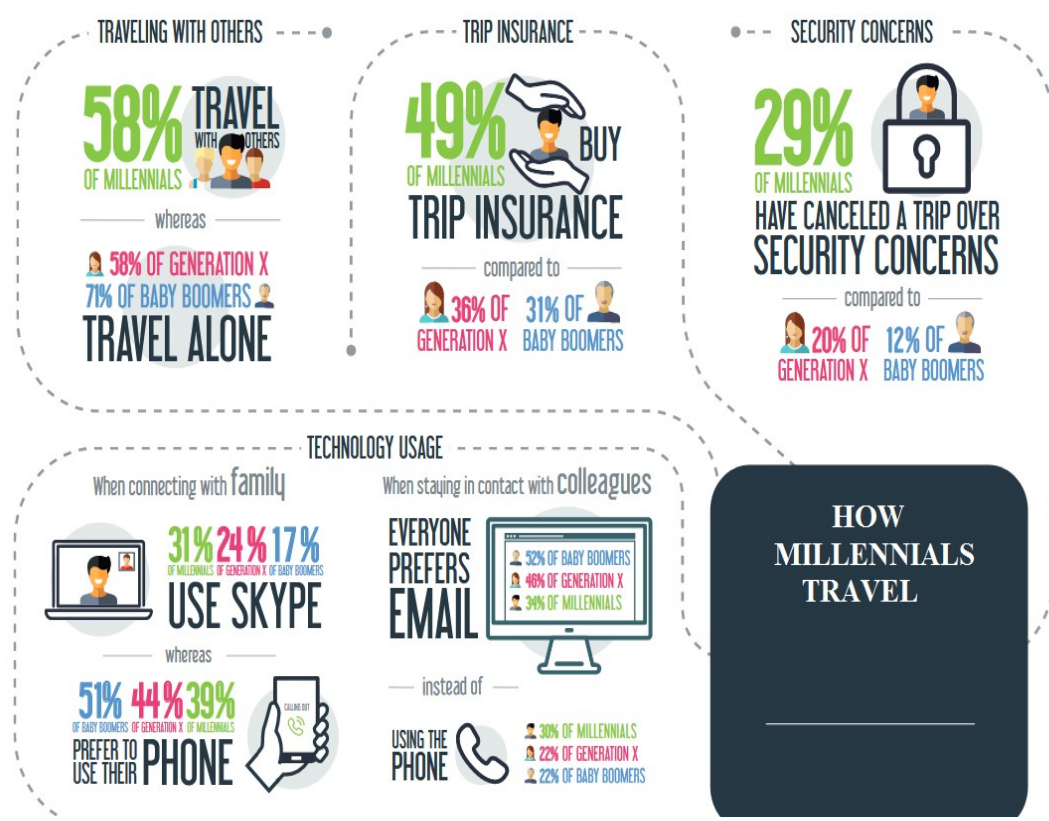

Fig. 3. How Millennials Travel

Source: "Millennials like to Travel in Groups - and Are the Most Security Conscious," accessed July 3, 2018, https://www.carlsonwagonlit.com/au/en/news/newsreleases/20171129-CWT-research--Millennials-like-to-travel-in-groups/

\section{How Change Millennials the Travel and Tourism Industry}

Millennials have primary interests like friends, fun and digital culture. They are confident and relaxed, relatively conservative in thinking, and, perhaps most importantly, the most educated generation in history.

Millennials have a major impact on the tourism industry. Those in this category travel more frequently, explore more destinations and spend more when they are on vacation; are in constant search for information and new sensations.

They have already begun to replace the old generation and this causes changes in the tourism industry in all its sectors. In a transition period, the millennials become the main segment as to the volume of services purchased. Thus, the tourism industry 


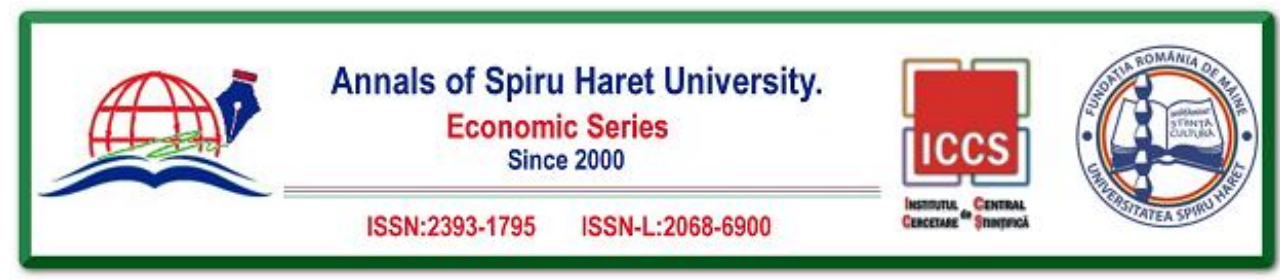

Issue 3/2018

has to adapt to this wave of travellers who are better acquainted with the offers they ask for.

Table 2. Trip Styles in Terms of Popularity for Millennials

\begin{tabular}{|c|c|c|}
\hline \multicolumn{3}{|c|}{ Top 10 trip styles in terms of popularity for millennials (\%) } \\
\hline 1. & Foodie Travel & $16 \%$ \\
\hline 2. & Business Travel & $14 \%$ \\
\hline 3. & Active adventures & $13 \%$ \\
\hline 4. & Island Hopping & $12 \%$ \\
\hline 5. & Sailling & $11 \%$ \\
\hline 6. & Sustainable Travel & $9 \%$ \\
\hline 7. & Music Travel & $8 \%$ \\
\hline 8. & Wildlife and safari & $7 \%$ \\
\hline 9. & Mountains and Trekking & $6 \%$ \\
\hline 10. & Spring Break & $4 \%$ \\
\hline
\end{tabular}

Source: personal contribution

Technology is not something new for the millenarians. They grew up with smartphones in their hand and benefited from innovative applications that make life seem a little easier. Hotels need to keep up with the times and technology.

Consideration needs to be given to developing facilities to meet the expectations of this category of customers, such as smartphone reservation applications, room service from the available tablet in the hotel room, extended loyalty programs, a commission that will make the stay as long as possible.

Millennials quickly attach to certain brands, requiring industry to begin implementing solutions that will ensure customer loyalty for the next five to ten years. In the era of permanent connectivity, the relationship between supplier and consumer must be reliable.

Social media have an extremely important role: a hotel unit can attract new customers by promoting services and interacting with those who spend time on this type of network. And the number of people who spend time on social networks daily is a significant segment.

Millennials have travel applications on their mobile phone, they prefer to reserve a phone call and make extensive research into the online environment before completing the booking of a particular property. For a hotel it is a 


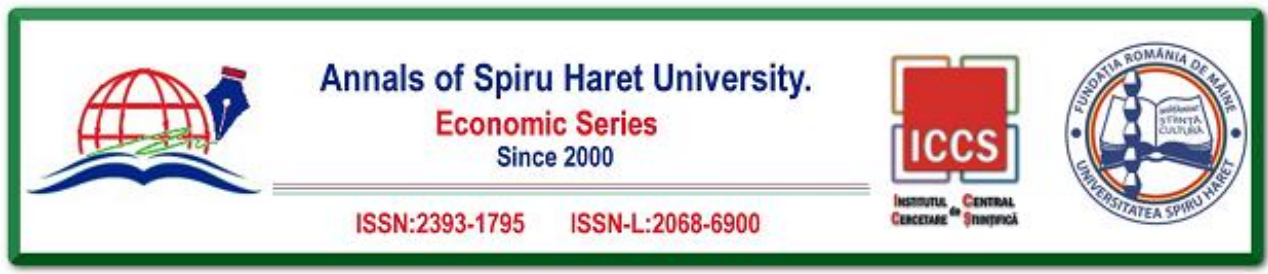

\section{Issue $3 / 2018$}

disadvantage if the website is not optimized for mobile. A hotel application would be an additional advantage that can prove profitable. The millennials want to have the information at their fingertips; they do not like to go to ask people information about the hotel or what they can do outside the hotel. Everything must be available through their smartphones.

The millennials want to get many services at a reasonable price. They want unique and accessible travel experiences at the same time. The millennials have not yet reached their maximum potential, but they are expected to take over the luxury segment between 2018 and 2020. But the millennials do not see luxury in the same way as previous generations, for whom luxury was spinning around a higher statute. Millennials do not attach such importance to statute; they want unprecedented experiences to share with their friends. They are always looking for new experiences.

Table 3. Most Popular Cities to Trip for Millennials

\begin{tabular}{|c|c|c|}
\hline \multicolumn{3}{|c|}{ Top 10 most popular cities to trip for millennials (\%) } \\
\hline 1. & Barcelona & $25 \%$ \\
\hline 2. & Madrid & $20 \%$ \\
\hline 3. & London & $11 \%$ \\
\hline 4. & Rome & $10 \%$ \\
\hline 5. & Amsterdam & $9 \%$ \\
\hline 6. & Bangkok & $8 \%$ \\
\hline 7. & Tokyo & $6 \%$ \\
\hline 8. & Auckland & $5 \%$ \\
\hline 9. & Dublin & $4 \%$ \\
\hline 10. & Manila & $2 \%$ \\
\hline
\end{tabular}

Source: personal contribution

For an industry that's as fast-moving and competitive as the global travel and tourism industry, it's logical to look ahead; to seek opportunities to launch new products that appeal to new groups of consumers. The race is now on for major travel and tourism brands around the globe to understand the next generation of business travellers, honeymooners, family travellers and all the other adult consumers, who will, in the next two decades, be the main consumers of a whole variety of travel products and services. [Gen C Traveller, 2018]

Millennials are driving enormous change in the tourism industry. To properly understand how millennials are doing this, you have to get into the 'Millennial 116 


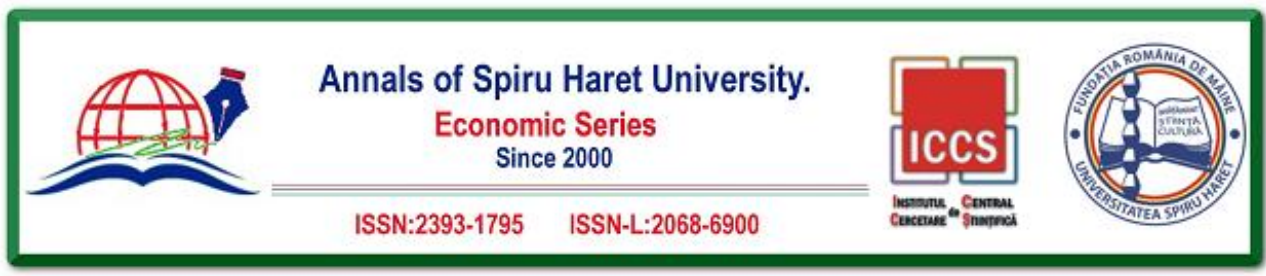

Issue 3/2018

mindset', by considering the events that have affected them, their values and their consumer choices outside the travel industry. It's also important to remember that millennials in different parts of the world are going through different experiences; there are some things that unite them, and others that cause them to behave differently when they travel. Therefore, I believe that it's essential to take a step back and look at millennials as consumers, their life choices, their experiences. [Gen C Traveller, 2018]

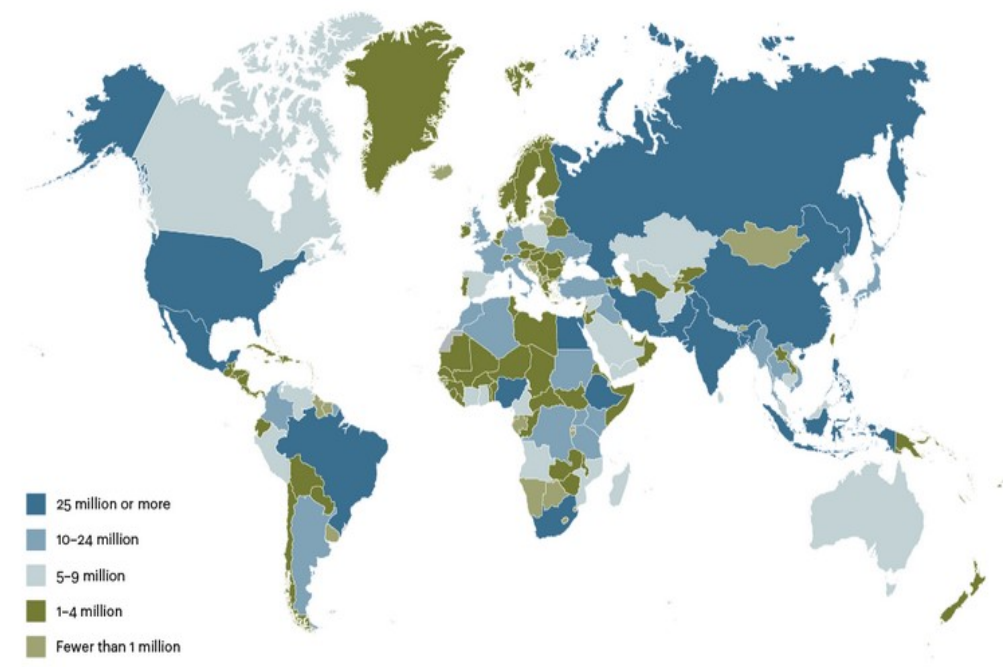

Fig. 4. Global Millennials Located by Countries

Source: "Where are the Global Millennials?," accessed August 3, 2018, https://www.atkearney.com/web/global-business-policy-council/article?/a/where-are-theglobal-millennials-

\section{The Importance of Millennials for the Tourism Industry}

Millennials are a savvy group that want better value when they travel and expect premium services. Their customer service demands are high and recognizing and responding to those demands will help create a stronger foothold with the catering market. [Crown Verity, 2018]

About 58 percent of global millennials live in Asia, including a whopping 385 million in India by far the largest domestic population of millennials in the world, and accounting for 19 percent of the global generational cohort. The next largest regional concentration is in Sub-Saharan Africa, which accounts for about 13 percent 


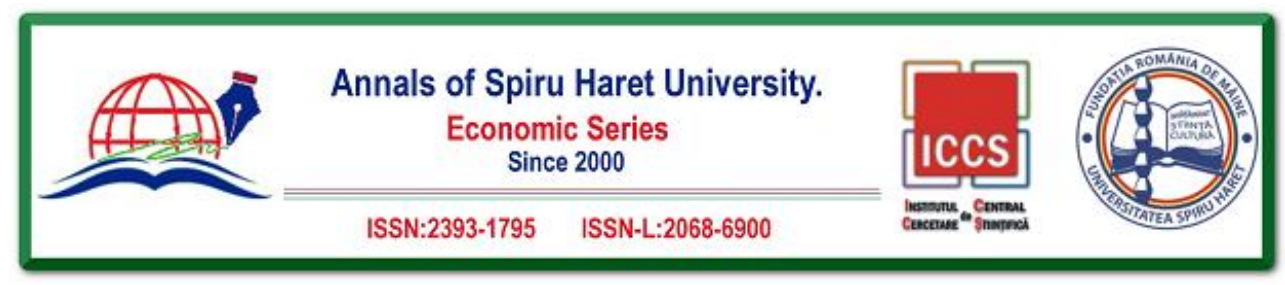

Issue 3/2018

of all millennials. This is hardly surprising given that these two regions also have the greatest overall populations, but it does point to their continued importance to consumer spending and potential economic growth in the coming decades. [ATKearney, 2018]

It is important to note that Europe and Asia are the only regions in which the millennial population varies more than a percentage point from their respective proportion of the global population. Asia is slightly overrepresented by its millennial population relative to its overall share of the global population (58 percent of global millennials vs. 56 percent of total global population). In contrast, the only region that is noticeably underweight on millennials is Europe ( 8 percent of global millennials vs. 10 percent of total global population). [ATKearney, 2018]

In absolute terms, India, China, the United States, Indonesia, and Brazil have the world's largest millennial populations (see fig. 4). Together they account for nearly half of the world's millennials. Again, this is unsurprising, as these five countries are also the most heavily populated. [ATKearney, 2018]

Although many millennials are approaching the period in their lives where family, mortgage and car payments are a financial reality, these double income households have greater disposable income than ever before and use that income for their own immediate comfort, pleasure and satisfaction. Their hotel preferences are largely driven by budget and their budget for luxury. [Crown Verity, 2018]

It is no longer enough to just hire staff. You must offer skilled and trained employees to meet the demands of the travellers with expectations that all travel reach a certain level of their standards. [Crown Verity, 2018]

Travellers are changing their expectations. Millennials are full of enthusiasm. They don't confine themselves to one place or even one continent. This generation has a sense of adventure. Their desire to experience the best travel opportunities possible and the demand to have those options readily available and modifiable to their particular needs is becoming more and more evident. [Crown Verity, 2018]

Millennials don't hope to be elite or at the top of social influence, they create it for themselves. Social media plays a huge role in how they view the world and themselves within that world. Their perception is reality and they make it that way. With friendship connections worldwide, travel referrals are made via social connections. Nearly half of all millennials will turn to people instead of businesses for advice on travel. For this reason it is imperative that hotels offer the best possible experience to every guest because that guest could be the connection to any number of other reservations. It is also a good reason for hotels and caterers to have a strong social media presence 


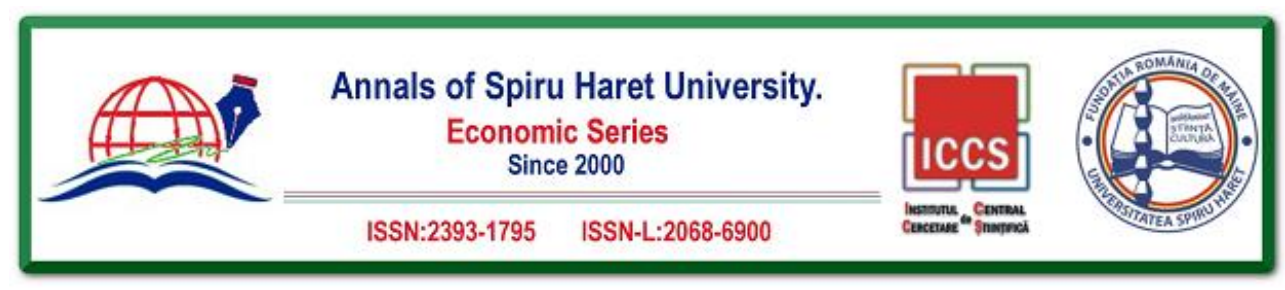

Issue 3/2018

through such outlets as Facebook, Twitter, and most importantly a website since millennials want to see what they are investing in. [Crown Verity, 2018]

The millennial demographic desire to connect with and share goes beyond just social media. However, as world travellers they are seeking greater opportunities to make connections with others within their own work industries and others that share their own specific interests. Hotels now find the need to invest in the basics of the hotel such as the lobby. That is the point of reference for the millennial. It's not just a room to sleep in but an overall environment to wrap themselves in what they believe is catered to their individual needs. Lobbies and common areas are no longer just check in spots but are becoming more and more about spaces designed and developed to offer social gatherings to their guests. [Crown Verity, 2018]

Millennial travellers will avoid staying at hotels that are not easily accessible. Many millennials choose not to drive, for whatever reason, so access to public transportation from hotels is important. Once at their chosen hotel millennials are demanding of the availability of one of a kind experiences and personal attention. [Crown Verity, 2018]

The millennial traveller looks for not just quality but exceptional, personalized service and demands it on the spot. Millennials want and seek out international standards of excellence in the hotel of their choice. Average meals, average accommodations and standard amenities will not cut it. Because millennials take extended holidays, business trips and even visit cities and stay for several days it is necessary to attract them with the comforts of home and the luxury of vacation. [Crown Verity, 2018]

In order to meet those expectations the hospitality is increasingly having to hire a higher qualified degree of personnel in hotel management, food and beverage management, casino management, club management, and tourism. [Crown Verity, 2018]

Millennials understand the importance of businesses that recognize the value in implementing green business practices. They also look for hotels that incorporate green procedures to reduce the demand on the environment such as reduction of linen change. [Crown Verity, 2018]

Millennials are also the fastest growing demographic of international travel accounting for around $20 \%$ of the current market and predicted to expand from 270 million visits to 320 million by 2020 as more begin to leave school, enjoy greater pay packets and the desire for travel continues to spiral. [Fiz, 2018] 


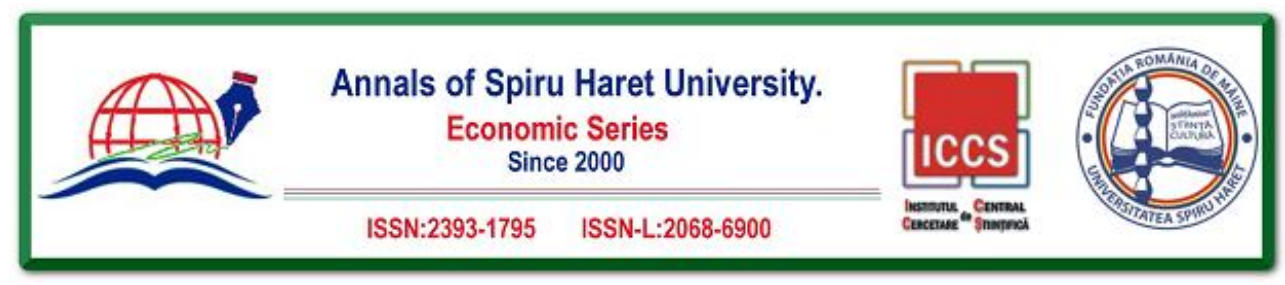

Issue 3/2018

It's now common knowledge that this generation wants to feel like a local rather than a brusque tourist. So part of the experience of travel is in really getting the 'feel' of a place. [Fiz, 2018]

This generation aren't content to be locked away in an all-inclusive beach side hotel (although, as we'll see, they wouldn't turn it down either). They want to feel in the thick of the action - hanging out in a local piazza, or browsing the local market. [Fiz, 2018]

This is partially to do with authorship, having the choice to go where you want and do what you want rather than be dictated to by the tour bus, or limited by the buffet selection. [Fiz, 2018]

They are also allergic to anything that appears false, fake, designed to appeal to tourists. This desire for choice and authenticity is enabled by the advent of personal, transportable technology. You can easily meet new people or book a remote mountainside log cabin with a few taps on your phone. [Fiz, 2018]

Thanks to millennials travellers, the 'experience' and 'tours' sector is booming and many companies are jumping on this expanding market. $\$ 135$ billion is the current worth of tours and activities and it's expected to breach $\$ 183$ billion by 2020. [Fiz, 2018]

While of course many millennials stay in a hostel and budget their travel, many are willing to fork out for a weekend yoga retreat, a mountain trek or even a luxury spa treatment. [Fiz, 2018]

When more expensive activities are seen as an 'event' the desire to be a part of it increases further. Joining a one off secret concert or seeing a rare cultural spectacle is worth spending on to 'live in the moment', take some great photos and feel a part of something bigger than yourself. [Fiz, 2018]

But it's not just one off splurges and back to basics after. There's been so much talk about this generation 'living like local' that we miss the bigger picture millennials want a bit of everything. [Fiz, 2018]

They want to go undercover, have a drink at a local bar, eat what the locals eat. But they also want to see the Mona Lisa at The Louvre, go to the British Museum and all the other classic tourist hotspots. They want it all, they want it now and they want the Instagram photo to go with it. [Fiz, 2018]

Millennials have transformed how the travel world operates and we're happy to say, so far, it seems for the best. Let's see what tomorrow brings. [Fiz, 2018]

Statistics about millennials [LeadsCon, 2018]: 


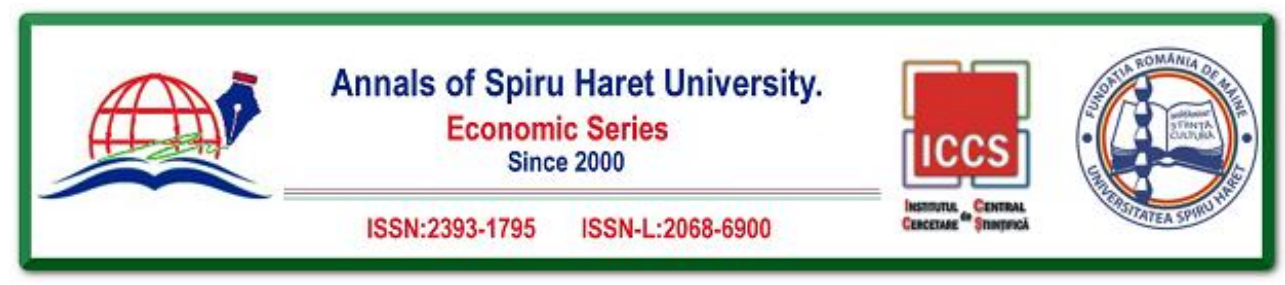

Issue 3/2018

-Globally, the aggregated net worth of millennials is projected to more than double from 2015 to 2020, skyrocketing to anywhere between \$19 trillion and \$24 trillion.

-Compared with consumers age 50 and over, millennials are over 10 times more likely to consider borrowing money through peer-to-peer lenders.

-43 percent of millennials don't think their bank communicates with them through preferred channels, such as mobile apps and text messages.

- Millennials favour mobile banking. During a typical month, millennials access their financial institution 8.5 times via a mobile app or browser versus 3.1 times for non-millennials.

-27 percent of millennials trust the virtual currency bitcoin.

-22 percent of millennials seek financial advice on social media, compared with 3 percent for people age 55 and over.

-47 percent of millennials have transferred money to someone electronically.

-Only 14 percent of millennials prefer to conduct banking activities in person.

\section{Conclusions}

In conclusion, although they have yet to reach their maximum potential, the millennials will have the most purchasing power in a few years, which means that it is now very important for each producer and service provider to gain the confidence and money of these young people through competitive methods.

The millennials are the ones who will pay more for experiences, not for products. But what is more important, they will not pay for trivial experiences, but for "different" experiences. If in the past people chose the busiest restaurant in the resort / town, new generations will look for themed restaurants on the sidewalks, with unique decoration and an adequate plating. Especially because the places they visit go through the social media filter.

Furthermore, millennials travelling for business purposes are accustomed to extending their journey a few days to discover local experiences. Hotels have adapted to this trend by offering extra-night at preferential rates, and restaurants have begun organizing so-called "after work" events. These events target young people who work in corporations and want moments of recreation after hours at the office.

The smartphone is the main gadget that millennials use to make a hotel reservation or for a flight ticket. 


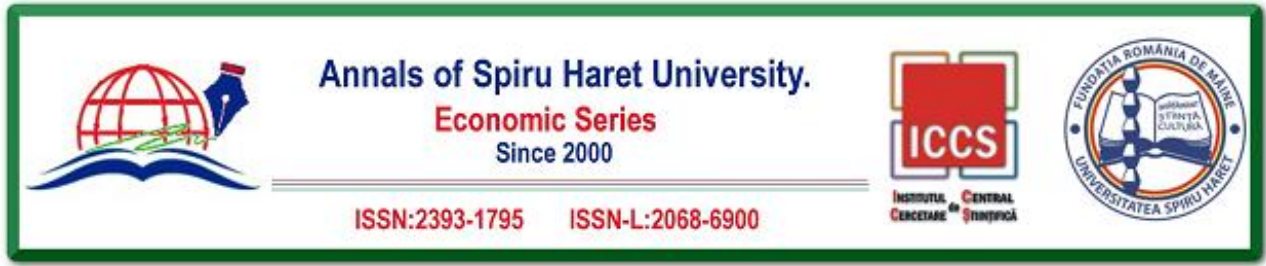

Issue 3/2018

Also, millennials are the ones who are planning a holiday on their phone. More than two-thirds of these tourists think it is more comfortable to plan their journey on the phone.

\section{References}

1. ATKearney (2018). "Where Are the Global Millennials?," accessed August 3, 2018, https:/www.atkearney.com/web/global-business-policy-council/article?/a/where-arethe-global-millennials-

2. Carlson Wagonlit Travel (2018). "Millennials Like to Travel in Groups - and Are the Most Security Conscious," accessed July 3, 2018, https://www.carlsonwagonlit.com/au/ en/news/news-releases/20171129-CWT-research--Millennials-like-to-travel-in-groups/

3. Crown Verity (2018). "The Millennials and Catering in the Hospitality \& Travel Industry," accessed July 5, 2018, https://www.crownverity.com/the-millennials-andcatering-in-the-hospitality-travel-industry/

4. Fiz (2018). "Millennial Travellers and How They've Changed Travel for the Better," accessed August 1, 2018, http://www.fiz.com/blog/travel-trends/millennial-travellers/

5. Gen C Traveller (2018). "Travel and Tourism for the Millennial Generation," accessed July 4, 2018, https://genctraveller.com/travel-and-tourism-for-the-millennial-generation/

6. LeadsCon (2018). "16 Statistics You Need to Know about Millennials and Money," accessed August 2, 2018, http://www.leadscon.com/16-statistics-you-need-to-knowabout-millennials-and-money/

7. Rezdy (2018). "Millennials: An In-depth Look into the Travel Segment," accessed July 2, 2018, https://www.rezdy.com/blog/millennials-depth-look-travel-segment-infographic/ 